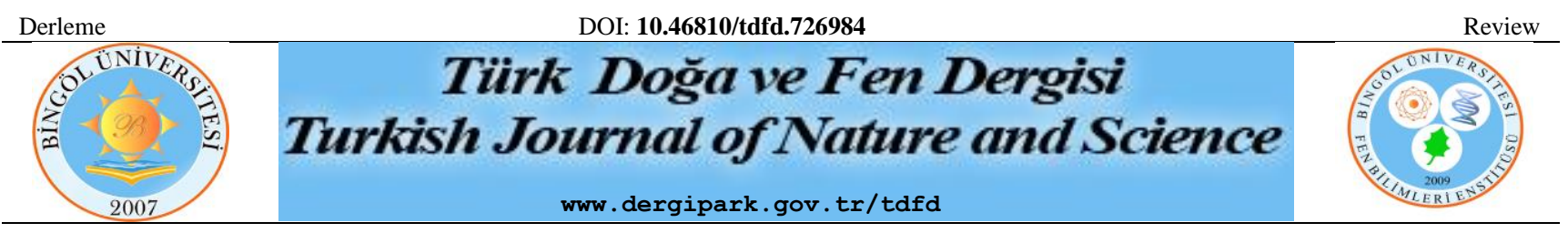

\title{
Yatalak İnek Sendromuna Güncel Bir Bakış
}

\author{
Ramazan KAMAN ${ }^{1}$, Akın KIRBAŞ ${ }^{2}$ * \\ ${ }^{1}$ Atatürk Üniversitesi, Veteriner Fakültesi, İç Hastalıkları Anabilim Dalı, Erzurum, Türkiye \\ ${ }^{2}$ Bozok Üniversitesi, Veteriner Fakültesi, İç Hastalıkları Anabilim Dalı, Yozgat, Türkiye \\ Ramazan KAMAN ORCID No: 0000-0001-6304-6063 \\ Akın KIRBAŞ ORCID No: 0000-0001-9159-3240 \\ *Sorumlu yazar: akin.kirbas@bozok.edu.tr
}

(Alınış: 26.04.2020, Kabul: 04.06.2020, Online Yayınlanma: 18.06.2020)

\begin{abstract}
Anahtar
Kelimeler

Yatalak

sendromu,

İnek,

Hipokalsemi,

Myopati,

Nöropati,

Tedavi

Öz: Yatalak inek sendromu (YİS) sistemik hastalık bulgusu göstermeksizin hipokalsemi tedavisine rağmen 24 saatten uzun süre sternal pozisyonda yatmaya devam eden inekleri tanımlamada kullanılan bir terimdir. Çok sayıda nedeni ve bunlara göre yönetimi bulunan kompleks bir durumdur. Hipokalsemi, hipomagnezemi ve hipokalemi gibi metabolik bozukluklar veya travmaya bağlı uzun süreli yatalaklıkta sekunder olarak gelişen arka bacak kaslarının iskemik nekrozisi ve sinirlerin hasarı ile ilişkilidir. Yatalak inekler genellikle uyanıktırlar ve başka bir bozukluktan etkilenmezlerse ruminasyona devam ederler. Şiddetli şekilde uyarılsalar bile ayağa kalkma çabaları isteksizdir. İnekler yanları üzerine uzanmış ve ayaklarını uzatmış halde bulunabilirler veya gögüsleri üzerinde yatarak bacaklarını karın altına bükerek ya da gergin şekilde uzanarak yatabilirler. Yatan ineklerde kalsiyum düzeyi normal iken fosfor ve potasyum düzeylerinde azalma tespit edilebilir. Aspartat aminotransferaz ve kreatin fosfokinaz aktivitelerinde artış, proteinüri, myoglobinüri ve ketonüri görülür. Tedavide nonsteroid anti-inflamatuvar ilaçlar kullanılabilir. Basınca bağlı bozukluklardan kaçınmak için yataklıkların değiştirilmesi ve ineklerin sık sık çevrilmesi sağlanmalıdır.
\end{abstract}

\section{A Current Overview of Downer Cow Syndrome}

Keywords
Cow,
Downer
syndrome,
Hypocalcaemia,
Myopathy,
Neuropathy,
Treatment

\begin{abstract}
Downer cow syndrome (DCS) is a term used to describe cows who continue to lie in the sternal position for more than 24 hours despite treatment of hypocalcemia without showing any signs of systemic disease. There are a large variety of causes and their management is complex. Downer cow syndrome is associated with metabolic disorders such as hypocalcaemia, hypomagnesaemia and hypokalemia, or ischemic necrosis and nerve damage of the hind limb muscles that develop in the prolonged bedridden due to trauma. The recumbency cows are usually awake and continue rumination if they are not affected by another disorder. Efforts to stand up are reluctant, even if they are warned violently. The cows can lie on their sides and stretch their feet, or lie on their breasts, lying down by bending their legs under the abdomen or lying stretched. While the calcium level is normal in the recumbent cows, a decrease in phosphorus and potassium levels can be detected. Increased aspartate aminotransferase and creatine phosphokinase activities, proteinuria, myoglobinuria and ketonuria are observed. Nonsteroidal anti-inflammatory drugs can be used in the treatment. To avoid pressure-related defects, changing the bedding and turning the cows frequently.
\end{abstract}

uygulanmış ve 24 saat içerisinde kalkamayan inekleri

\section{GİRİ̧̧}

Downer cow (yatalak inek) terimi 1950'li yıllardan bu yana kullanılmaktadır. Ancak halen dünyaca kabul görmüş bir tanımı bulunmamaktadır [1, 2]. Björsell ve Holtenius [3], hipokalsemiye karşı kalsiyum tedavisi yatalak olarak tanımlamıștır. Fenwick [4], kalsiyum uygulamasına rağmen 10 dakika içinde kalkamayan inekleri yatalak olarak tanımlamıştır. Cox [5], herhangi bir sistemik hastalık bulgusu göstermeksizin 24 saatten uzun süre sternal pozisyonda yatan inek olarak tanımlamıştır. Bazı yazarlar, yatar halde yiyip içebilen 
ancak ayağa kalkamayan alert inek olarak tanımlamıştır [6]. Burton ve ark. [7] 12 saat veya daha uzun süre ayağa kalkamayan veya ayakta durmakta isteksiz olan inekleri yatalak olarak tanımlamıştır. Richter ve Götze ile Hofman ve Elamrousi kendiliğinden ayağa kalkamama olarak tarif etmelerine karşın, Jönsson ve Pehrson doğum felcine karşı iki kez tedavi yapılmasına rağmen ayağa kalkamayan hastalar olarak ve Oksanen ise özel bir güç ile ayağa kalkamayan inekler olarak tanımlamışlardır [8]. Bazı araştırmacılar, yatalak sendromunun bir hastalık olmayı altta yatan asıl problemlerin komplikasyonu olduğunu belirtmişlerdir $\left[\begin{array}{ll}9, & 10\end{array}\right]$. Downer cow, çoğunlukla doğum sonrası dönemde hipokalsemi ve hipofosfotemi'nin bir komplikasyonu olarak ortaya çıkar $[11,12]$. Vakalar her ne kadar doğum öncesi dönemde de görülse de genellikle hipokalsemi tedavisi gören ve ayağa kalkamayan inekler sendrom kapsamında incelenmiştir [13]. Fakat kalsiyum ve fosfor seviyeleri normal, herhangi bir kas-iskelet hasarının veya mastitis-metritis tablosunun bulunmadığı halde yatalak olan inekler mevcut olup bu gibi durumlar teşhis ve tedavi açısından veteriner hekimlere her zaman güçlük çıkaran bir tablodur [14]. Downer cow etiyolojik faktörler ve klinik bulgularına göre alert (uyanık) ve non-alert (depresif-uyanık olmayan) olmak üzere iki grupta incelenebilir. Alert downer cow, yeme içme faaliyetleri devam eden ve diş uyarımlara normal şekilde tepki vermesine rağmen ayağa kalkamayan ve sternal pozisyonda yatan, non-alert downer cow ise anormal yaşamsal faaliyetleri ve davranışları bulunan ve lateral uzanan hayvanlar olarak tanımlanabilir $[6,7,17]$. Bu derlemede, yatalak inek sendromunun etiyolojisi, epidemiyolojisi, klinik bulguları, patogenezi, laboratuvar bulguları ve tanıya yaklaşım kriterleri, tedavi planı ve korunma yöntemleri üzerine güncel bilgilerin sunulması amaçlanmıştır.

\section{ETIYYLOJI ve PATOGENEZ}

Yatalaklığın oluşumunda çok sayıda nedenin olduğu belirtilmektedir [18]. Ancak yaygın nedenleri dört ana başlık altında toplanmıştır (Tablo 1) [19].

Tablo 1: Yatalak inek sendromunun yaygın etiyolojik faktörleri [19]

\begin{tabular}{llll}
\hline Travmatik & Metabolik & Nörolojik & Toksemik \\
\hline Pelvis kırıkları & Hipokalsemi & Obturatör sinir felci & Akut E.coli mastiti \\
Sakroiliak çıkıklar & Hipofosfotemi & Siyatik sinir felci & Akut metritis \\
Gastrocnemic tendo hasarları & Hipomagnezemi & Periferal sinir felci & Abomazumun sağa deplasmanı \\
Güç doğum & Karaciğer yağlanması & Bovine spongioform & Volvulus \\
Uterus yaralanma ve kanamaları & & Botilusmus & Peritonitis \\
& Rumen asidozu & Tetanoz & Yüksek ateş
\end{tabular}

Birçok etiyolojik faktör, ineklerde yatalaklık ile ilişkilendirilmektedir. Ancak bunlardan bazıları zayıf olarak, bazıları ise kuvvetli etken olarak tanımlanabilir. Bunlar; doğum sonrası felç kompleksi, hipofosfotemi, hipomagnezemi, hipokalemi, hiper veya hipo adrenokortikal aktiviteler, serebral ödem, albuminüri, renal hastalıklar, karaciğer hastalıkları ve kas dejenerasyonları ile fiziksel yaralanmalardır [20]. Bazı araştırmacılar, downer cow sendromunun etiyolojisinin net olmadığını ve süt hummasının veya başka bir hastalığın komplikasyonu olduğunu ifade etmişlerdir [9, 15]. Beslenmenin yatalaklığın etiyolojisinde etkisinin olduğu ve fazla sodyum $(\mathrm{Na})$ tüketiminin, yetersiz kalsiyum (Ca) alımının ve genellikle yüksek enerji ile beslemenin downer cow oluşumunda etkili olduğu öne sürülmüştür. Bununla birlikte, yüksek proteinli rasyonlar, yetersiz gida alımı, vitamin, iz element ve mineral yetersizliği gibi beslenme hataları da etkili olmaktadır [10, 21]. Özellikle güç doğumlar esnasında pelvik kanalda buzağının ilerlemesi esnasında oluşan basınç ile siyatik ve obturator sinirlerin yaralanması sonucu yatalaklık oluşabilir. Bunun akabinde yatalaklığa bağlı olarak radiyal ve peroneal sinirlerde de yaralanmalar meydana gelebilir [22]. Poulton ve ark. [23] bir günden uzun süre yatan hayvanlarda oluşan sekunder hasarlardan dolayı yatalaklığın ana sebebinin tanımlanamadığını ifade etmişlerdir. İneklerin uzun süre aynı pozisyonda sert zemin üzerinde yatmaları sonucu Mm. adductore, Mm.fibularis tertius gibi kaslarda yırtıklar oluşması, dejenerasyonları ve nekrozları yatalaklığın asıl sebebi olabileceği gibi yatalaklık durumunda oluşacak basınç sonucu diğer kas ve dokularda oluşan hasarın da yatalaklığın etiyolojisinde etkili olacağ 1 belirtilmektedir. Özellikle 6-12 saat sert zeminde yatan ineklerin arka bacaklarının yüzeysel ve derin dokularında hasar oluşmasının her zaman mümkün olduğu belirtilmiştir [12]. Pehrson, yatalaklığın gelişiminin değişken olabileceğini ve yatalaklığın etiyolojisinde $\% 70$ bacak kas ve sinirlerinde oluşan hasarın, \%10 myokarditis, \%8 hepatitis, $\% 5$ nüksedici hipokalsemi ve $\% 7$ bilinmeyen sebeplerin rol oynadığını belirtmiştir [24].

Yatalak inek sendromu yüksek süt verimli hayvanlarda yüksek oranda doğum sonrası ilk 2-3 gün içinde ve sıklıkla hipokalsemi ile birlikte görülür. $\mathrm{Bu}$ hipoteze göre, hipokalsemi veya iskemiden dolayı uzayan yatalaklık kas hücrelerinin membran geçirgenliğinin artmasına ve potasyumun hücre dışına çıkmasına bağlı olarak myotoni oluşmasına neden olmaktadır. Bu durum yatalaklığın temelini oluşturmaktadır [25]. Yatalaklık en 
s1k olarak doğum sonrası ilk bir gün içinde meydana gelir ve sıklıkla hipokalsemi veya doğumla ilişkili komplikasyonlar ile sonuçlanır [5, 12, 22, 26, 27]. Bir çalışmada, 12 Holştayn inek sürüsünde, doğum sonrası 1 ay içinde yatalaklığın risk faktörleri değerlendirilmiş, tüm risk faktörleri içinde \%5,6 klinik hipokalsemi, \%4,9 ölü doğum, \%5,7 güç doğum ve $\% 6,1$ retensiyo sekundinarum olarak belirtilmiştir. Bunların dışında paraliz, septik metrit ve mastitisinde yatalaklığın oluşumunda ana etken olabileceği ifade edilmiştir [26]. Başka bir çalışmada ise ayağa kalkamamanın 3 ana sebebi tespit edilmeye çalışılmış ve \%19 hipokalsemi, $\% 22$ doğuma bağlı yaralanmalar ve \%15 kaymadüşmeye bağlı yaralanmalar olarak belirlenmiştir [28].

Cox, yatalaklığın muhtemel nedenini açıklamak için basınca bağlı hasar ve kompartman sendromu olarak ele alınmasını önermiştir. Kompartman sendromu osteofasiyal kompartman içinde oluşan basınç hasarını ifade etmektedir. Osteofasiyal kompartman, aynı hareketi sergileyen, aynı sinir tarafindan uyarılan ve kalın bir fasiya ile sarılmış olan kas gurubudur. Bilinen en gelişmiş osteofasiyal kompartman olarak eksremitelerin proksimal alanlarındaki kas grupları tanımlanmıştır (Mm. biceps femoris, Mm. semitendinosus ve semimembranosus). Artan basınç, osteofasiyal kompartman içinde ya eksternal ya da internal basınç artışıyla veya her ikisiyle de sonuçlanabilir. Eksternal basınç damar daralmasına, iskemi, dolaşım yetmezliği ve basınç alanında ödeme bağlı şişmelere yol açar ki bu da internal basınç artışına sebep olur. Kas hasarlarının sistemik etkisi, renal hasarlar, kardiyak aritmi ve artan kreatin kinaz aktivitesi insan hekimliğinde tanımlanan Crush sendromu ile açıklanmıștır [1,2,22].

Yüksek süt verimli ineklerde önemli bir yer tutan metabolik hastalıkların oluşumunda stres, vitamin, iz element, protein ve enerji yetersizliği gibi faktörlerle beraber, özellikle $\mathrm{Ca}, \mathrm{P}, \mathrm{Mg}$ ve $\mathrm{K}$ iyonlarının yetersizliği ve bunlar arasındaki dengesizlikler periparturient ve postparturient parezislere neden olmaktadır [25,29-32]. İneklerde periparturient dönemde oluşabilecek hipofosfotemi, hipomagnezemi ve hipokalemi gibi metabolik durumlar kas ve sinir fonksiyonlarına olumsuz etkileri nedeniyle ineklerin hareket etme ve ayağa kalkma fonksiyonlarını ortadan kaldırabilirler. $\mathrm{Bu}$ minerallerin kan konsantrasyonlarındaki az miktardaki değişimler ise; gıda alımında azalma, verim kaybı ile diğer metabolik ve enfeksiyöz hastalıkların oluşmasına zemin hazırlamaktadır [25]. Hipomagnezemi, Mg'un uzun süre düşük seviyede seyretmesi ve hipokalsemiyle birlikte bulunması yatalak inek sendromu ile ilişkilendirilmiştir. Hipomagnezemiye, yemlerdeki $\mathrm{Mg}$ noksanlı̆̆ yeteri kadar $\mathrm{Mg}$ emilememesi ve intraselüler $\mathrm{Mg}$ değişimleri gibi faktörler neden olmaktadır [33,34]. Hipokalemi; hipokalsemiye bağlı uzun süre yatalaklık durumunda gelişen iskemi ve kas liflerinde meydana gelen hücre membran permeabilitesindeki artışa bağlı olarak gelişerek hücreden K kaybına yol açar. Bunun sonucunda oluşan myotoni yatalaklığa sebep olabilir. Yatalaklık tanısı konulan ineklerin, kan K seviyelerinin düşük olması bu durumu desteklemektedir [34].
Yatalak inek sendromunun gelişiminde enfeksiyöz etkenlerin de rol oynadığı belirtilmektedir. Nörolojik bozukluklara yol açan bazı viral, bakteriyel ve paraziter enfeksiyonların ineklerde yatalaklığa neden olabileceği belirtilmiştir. Bovin viral diyare (BVD) ile yatalak inek sendromu (YİS) arasında bir ilişki olup olmadığını tespit etmek amacıyla yapılan bir çalışmada, yatalak olarak tespit edilen 2-7 yaş aralığındaki 386 ineğin kan serumu ve beyin dokularında anlamlı sonuçlar elde edilerek, yatalaklığın etiyolojisinde BVD gibi viral bir etkenin olabileceğini vurgulamışlardır [35]. Rullf ve ark. [36] 52 yatalak inek üzerinde yaptıkları çalışmada, yatalak ineklerde C. botulinum A, B, E, C ve D toksinleri antikor seviyelerini anlamlı derecede yüksek tespit ederek Botilusmus'un yatalak sendromunda predispoze bir faktör olabileceğini belirtmişlerdir.

Karaciğer yağlanması downer cow oluşumunda önemli bir risk faktörüdür [37]. Yüksek süt verimli inekler erken laktasyon döneminde negatif enerji dengesi içerisindedir ve enerji gereksinimleri rasyonla aldıklarından daha fazladır [38]. Karaciğer metabolizmada merkezi bir rol oynamaktadır ve özellikle yüksek süt verimli ineklerde doğum öncesinde veya sonrasında karaciğer yağlanması oluşabilir [39,40].

Julien ve ark. [21] rasyondaki fosfor ve protein durumunun downer cow sendromu ile ilgisini inceledikleri çalışmalarında, kuru dönem başında olan 53 baş ineği 4 gruba ayırıp bütün hayvanları mısır silajı ve konsantre yem ile beslemişlerdir. İlk iki gruba \%8 HP içeren rasyon verirken, diğer iki gruba \%15 HP içeren rasyon vermişlerdir. Bununla birlikte rasyonları 1. ve 3 . gruplara toplam kuru maddenin \%0,65'i Ca ve \%0,29'u $\mathrm{P}$ içeren, 2. gruba \%0,70 Ca ve $\mathrm{P}$ içeren, 4. gruba ise $\% 0,66 \mathrm{Ca}, \% 0,65 \mathrm{P}$ içerecek şekilde düzenlemişlerdir. Yüksek protein alan 3 ve 4 . gruplarda yaklaşık \%69,2 oranında doğum sonrası metabolik bozukluklar şekillenmiş; bunlardan 8 tanesine downer cow teşhisi konulmuş, 6 tanesi tedaviye yanıt verip düzelirken iki tanesi tedavi esnasında ölmüştür. Düşük proteinle beslenen gruplarda ise metabolik bozukluk \%7,14 olarak tespit edilmiş ve hiç birisinin downer cow olmadığ belirtilmiştir. $\mathrm{Bu}$ nedenle rasyondaki protein oranının doğum sonrası metabolik hastalık görülme ihtimalini arttırabileceği, rasyondaki mineral madde düzeyindeki değişimlerden ziyade protein oranının downer cow oluşumunda etkili olacağı değerlendirilmiştir. İntravenöz fosfor bileşikleri ile tedavi edilen bazı yatalak hayvanlardan olumlu yanıt alınması yatalaklığın yaygın bir sebebinin de fosfor eksikliği olabileceğini göstermiştir. Hipokalemi sıklıkla hipofosfotemi ile ilişskilendirilmiş ve bazı yatalak hayvanlarda serum ve kas K seviyeleri düşük tespit edilmiştir [41].

\section{EPIDEMIYYOLOJI}

Downer cow sendromuna ilişkin risk faktörleri ve yaş ile olan ilişkisine dair veriler sınırlıdır. Fakat yaşlı hayvanlarda süt humması ve düvelerde güç doğum en ciddi risk faktörleridir [42]. YİS'in insidansını tespit etmek, hastalığın tanımlanmasının yoruma açık olduğundan dolayı çok zordur [26]. Bazı kaynaklarda 
tüm süt humması vakalarının \%3,8 ile \%28,2 oranlarında alert downer cow olarak sonuçlandığı ve bunların mortalite oranlarının \%20-67 arasında olduğu belirtilmektedir [6]. Cox ve ark. bir anket çalışmasında downer cow insidansını 21,4/1000 baş inek olarak tespit etmiş ve bunlardan \%33'ünün düzeldiğini, \%23'ünün kesimhaneye gittiği ve \%44'ününde öldüğünü, bu vakaların yaklaşık \%58'inin doğum sonrası ilk 24 saat içinde ve \%37'sinin laktasyonun ilk 100 gününde şekillendiğini belirtmişlerdir. Aynı çalışmaya göre İsviçre Esmeri 1rk1 15,7/1000 baş inek, Holstein Irk1 $22,2 / 1000$ baş inek, Jersey 1rk1 17,9/1000 baş inek ve Guernsey 1rk1 21,8/1000 baş inek olarak tespit edilerek 1rkların yatalaklığa karşı predispozisyonu hakkında bilgi vermiştir. Ayrıca, yatalaklığın mevsim olarak en çok soğuk kış ayları olan Aralık, Ocak ve Şubat aylarında en az ise Nisan, Mayıs ve Haziran aylarında meydana geldiği tespit edilmiştir [43]. YİS yüksek oranda doğum sonrası ilk 2-3 gün içinde görülür. Koliform mastitis ve enerji dengesi bozukluklarına bağlı olarak da inekler yatma eğilimi gösterebilir. Hastalık hipokalseminin bir komplikasyonu olarak yüksek süt verimli ve ekonomik olarak değerli olan ineklerde daha yüksek oranlarda görülmektedir [10]. Correa ve ark. [26] 2705 sağmal hayvan üzerinde yaptıkları bir çalışmada, kümülatif postpartum insidansını \%1,1 olarak tespit etmişlerdir. Ayrıca, klinik hipokalsemi ve ölü doğumun downer cow riskini 5 kat arttırdığını ifade etmişlerdir. Periparturient hipokalsemi vakalarının \%3,8-28'inin yatalaklık tablosu oluşturduğu, vaka ölüm oranının ise \%20-67 arasında olduğu rapor edilmiştir [11,17,34]. Vakaların çoğunlukla ineklerin süt verimlerinin yüksek olduğu 4-6 yaşlarında, doğum öncesi 2 ile doğum sonrasi 10. günler arasında daha sık görüldüğü bildirilmektedir. İri yapılı ve yüksek kondisyonlu inekler ile geçmişte hipokalsemi tedavisi görmüş inekler risk grubundadır. Bakım ve besleme hataları, uygun olmayan işçilik, kaygan zeminler, periparturient dönem yönetimi, mevsim ve çevresel faktörler, işletme ve yönetime bağlı risk faktörleri olarak sayılabileceği gibi, hipokalsemi tedavisinin geç ve yetersiz yapılması ve uzun süre hayvanın sert zeminde aynı yönde yatması ineğe bağlı temel risk faktörleri olarak siralanabilir [10].

\section{KLINIIK BULGULAR}

Doğum sonrası inekler hipokalsemi veya hipomagnezemi gibi çözülmemiş bir metabolik rahatsızlıktan dolayı lateral uzanmış halde bulunabilir. $\mathrm{Bu}$ durumdaki inekler donuk, isteksiz ve neşesiz bir görüntüye sahiptirler. İkinci önemli bir ihtimal ise toksemiye bağlı depresyon, genital bölge veya memeye bağlı sorunlardır [16]. Klinik değerlendirmede amaç, downer cow sendromunun derecesini ve yatalaklığın asıl sebebini tanımlamak üzerine olmalıdır. Fakat yatan ineklerde tüm vücudu muayene etmek mümkün olmayabilir [44].

Yatalak sendromlu inekler genellikle uyanıktır ve artan rahatsızlığın verdiği istıraptan dolayı çoğunlukla ruminasyona devam edemezler. Ayağa kalkma çabaları genellikle isteksiz ve zorlayaraktır. Ancak her ne kadar ayağa kalmaya zorlansa da bunu başaramazlar.
Genellikle insanların bulunduğu ortamlarda cansız ve tepkisiz dururken yalnız kaldıkları zaman ayağa kalkmak için çok fazla efor sarf ederler ancak yine de başaramazlar. İneklerin çoğu sürünme çabaları gösterirler. Bulundukları padok içerisinde veya önlerindeki alan boyunca ayağa kalmak için sürünerek ilerlerler [41]. İlk bakışta yatalak sendromunun klinik belirtileri hipokalsemi ile benzerlik gösterir. Fakat bu hayvanlar uygun hipokalsemi tedavisine rağmen ayağa kalkamazlar [13]. Bazı ineklerde lateral pozisyonda yatma, ekspirasyonda inleme ve kan izleri taşıyan mukoid bir dışkıya sahip oldukları gözlenmiştir [4]. YİS bağımsız oluşabildiği gibi, hipokalsemi tedavisinden sonraki belirgin düzelmelerden sonra da gelişebilir. Hipokalsemili ineklerin yaklaşık \%30'u tedaviyi takiben 24 saat içerisinde ayağa kalkamazlar. Hipokalseminin bu formu ile iki kalsiyum uygulamasına rağmen YİS'li inekler ayağa kalkamazlar. Bazı olgularda kalsiyum uygulamasını müteakip taşikardi ve aritmi meydana gelerek ölüm şekillenebilir [12].

Alert (uyanık) form; vücut sıcaklığı, kalp frekans1, ürinasyon ve defekasyon normal iken iştahın azalabileceği, kalp frekansının bazen yükselebileceği ve kas hasarına bağlı olarak idrar renginin değişebileceği ve kahverenginde olabileceği bildirilmektedir. Bu formdaki hayvanlar özellikle ön ayakları ile ayağa kalkmaya çabalarlar [12,26,45-47]. Bazı durumlarda abdominal organların diyaframa yapacağı basınçtan dolayı solunum güçlüğü görülebilir [16].

Non alert (depresif) form; iştahsızlık, dehidrasyon, endotoksemi, hiperestezi, tetani ve kalkma çabalarının olmamasiyla beraber lateral pozisyonda yatma hali görülür $[16,46]$. Yatalak ineklerden bazıları dört ayağını gergin şekilde uzatıp lateral pozisyonda yatarken bazıları göğüs üzerinde durarak arka ayaklarını uzatabilirler. İnekler ayağa kalkmayı denedikleri zaman çok zorlanabilirler ve bu durumda topuk eklemlerinde veya arka bacak eklemlerinde ciddi hasarlar meydana gelebilir. Bazen inekler arka bacaklarını toplayarak köpek gibi oturabilirler fakat bu durumda ayağa kalkamaya çalışmayacaklardır. Genellikle arka bacaklarda normal sinirsel iletim devam etmektedir ve arka bacaklara yapılacak uyarımlara yanıt verebilirler [41].

Eğer yatalaklık uzamış veya güç doğumdan dolayı şekillenmişse genellikle vulva aşırı şekilde şişmiştir ve bol miktarda akıntı oluşacaktır [41]. Vaginal muayene her doğum sonrası yapılmak zorundadır çünkü yatalaklık bütünlüğü bozulmuş bir buzağıdan dolayı gelişen enfeksiyon veya hasardan dolayı oluşmuş olabilir. Metritise bağlı toksemi yatalaklığa neden olabilir. Ayrica, rektal palpasyon veya vaginal muayene sonucu uterus involusyonun pospartum güne uygun olup olmadığı, uterus içeriğinde sıvı birikimi olup olmadığı ve uterus tonositesi kontrol edilebilir [16]. Bacak eklemlerinin hiperfleksiyonu oluşursa peroneal sinir hasarı ihtimali yüksektir. Bu durumda bacaklar ineklerin iki yanından öne doğru uzanır, hatta dirseklere kadar gelebilir. Bu duruma bağlı olarak medial kaslarda basınç 
artışı nedeniyle şiddetli iskemik nekrozlar ve eklemlerde rahatsızlıklar ortaya çıkar [12].

Yatalak hastalara klinik yaklaşımda; sistemik başka bir hastalığın olma ihtimaline karşın ateş, nabız, solunum muayeneleri, rektal ve vaginal muayeneler, meme, pelvis, uterus ve bacaklar özenle muayene edilmelidir. Yeni doğum yapmış ineklerde olma ihtimali yüksek olan metritis, mastitis, toksemi veya gastrointestinal hastalıklar, dehidrasyon veya şok oluşturabilen akut septik peritonit ve aşırı karbonhidrat tüketimine bağlı hastalıklar yönünden muayene edilerek primer hastalık var ise tespit edilmelidir. Travmaya bağlı oluşabilecek koksafemoral eklem çıkıkları ve kolumna vertebralis kontrol edilmelidir [10].

\section{LABORATUVAR BULGULARI}

Laboratuvar testleri tüm şartlar sağlandığı zaman yatalaklığın sebebini tespit etmek için uygun olabilir. Ancak bu her zaman muhtemel ve mümkün olmayabilir [6]. Downer cow olarak rapor edilen bazı çalışmalarda serum $\mathrm{Ca}, \mathrm{P}$ ve bununla birlikte $\mathrm{Mg}, \mathrm{K}$ ve glukoz seviyelerinin azaldığ ve glukoz konsantrasyonlarının hematolojik parametrelerin fizyolojik sınırlar içerisinde olduğu rapor edilmiştir $[15,49]$.

Yatalaklığın başlangıcından $18-24$ saat sonra serum kreatin fosfokinaz (CK) ve aspartat amino transferaz (AST) enzim aktivitelerinin arttığı bildirilmiştir. Bu artış yatalak gün sayısına paralel olarak artış göstermeye devam etmektedir. CK aktivitesindeki artışın basınca bağlı kas hasarı olduğu muhtemeldir [15]. AST seviyesindeki artışın karaciğer hasarına bağlı olarak mı yoksa kas hasarına bağlı olarak mı olduğunu anlamak kolay değildir. Bunun için CK seviyesinin AST seviyesi ile birlikte artması kas hasarı için önemlidir [50]. Yapılan bir çalışmaya göre, yatalak ineklerde serum AST, laktat dehidrojenaz (LDH) ve CK enzim aktivitelerinde yüksek artış gözlenirken diğer biyokimyasal parametrelerde değişim saptanmamıştır [49].

Biyokimyasal analizler downer cow'da kas hasarını veya basınca bağlı hasarları değerlendirmek için kullanılabilir, ancak kesin veri sağlamaz [2]. Cox ve ark. [51] tarafından yapılan deneysel bir çalışmada CK seviyesinin yatalak grup ile yatalak olmayan grup arasında ilk 24 saat içerisinde önemli bir fark olmadığı tespit edilmiştir. Ancak 48 ve 96. saatlerde yapılan ölçümlerde önemli derecede bir fark olduğunu bildirmişlerdir. Blood ve ark. [15]'da $\mathrm{Ca}, \mathrm{P}, \mathrm{Mg}$ ve glukoz seviyelerini yatalak ineklerde normal fizyolojik sınırlar içinde bildirmişlerdir. Clark ve ark. [52] Yeni Zelanda'da 433 yatalak inekte yaptıkları çalışmada, yatalaklığın ilk 7 gününde $\mathrm{CK}$ düzeylerindeki değişimleri değerlendirmişler ve buna göre 12. saatte CK seviyesini normalden 33 kat, 1.günde 50 kat, 3. günde 38 kat, 5. günde 23 kat ve 7 . günde 10 kat fazla olarak belirleyerek kritik seviyeyi aşan hayvanların hayatta kalma oranını \%5'ten az olarak bildirmişlerdir [52]. Aynı çalışmada yatalaklık günlerine göre serum AST seviyeleri belirlenmiş, ancak CK tespitindeki gibi günlere göre bir kritik değer tespit edilememiştir. Ancak 890 U/L'nin üzerinde tespit edilen değerlere sahip hayvanların yaşama şansının $\% 5$ 'ten az olduğu belirtilmiştir [52]. Ayrıca bu çalışmada 267 yatalak inekte, serum üre konsantrasyonları $25 \mathrm{mmol} / \mathrm{l}$ 'nin üzerinde belirlenen 13 hayvandan hiçbiri kurtarılamazken serum üre konsantrasyonları 12,3 ile 25 $\mathrm{mmol} / \mathrm{l}$ arasinda belirlenen 37 hayvandan sadece 5 tanesinde iyileşme gözlenmiştir [52].

İz element seviyelerinin ölçüldüğü bir çalışmada $\mathrm{Fe}$ ve $\mathrm{Cu}$ seviyelerinin sağlıklı hayvanlara göre yatalak ineklerde daha düşük olduğu tespit edilirken $\mathrm{Mn}$ ve Co seviyelerinde ise herhangi bir fark bulunamamıştır [49].

Kalsiyum, $\mathrm{Mg}, \mathrm{K}$ ve $\mathrm{P}$ düzeylerinin araştırıldığ çalışmalarda farklı sonuçlar elde edilmiştir. Güzelbekteş ve ark. [48] 5 yatalak inek üzerinde yaptıkları çalışmada $\mathrm{Mg}$ ve $\mathrm{K}$ düzeylerinde önemli bir azalma tespit ederken $\mathrm{Ca}$ ve $\mathrm{P}$ düzeylerinde herhangi bir farklılık tespit edememişlerdir. Onmaz ve ark. [49] ise 20 yatalak inek üzerinde yaptıkları çalışmada $\mathrm{Ca}, \mathrm{Mg}$ ve $\mathrm{P}$ oranlarını normal değerler içinde tespit etmişlerdir. Diğer bir çalışmada ise $\mathrm{Ca}, \mathrm{P}$ ve $\mathrm{K}$ seviyeleri önemli ölçüde düşük bulunmuştur [53].

Oikawa ve ark. [31] tarafından karaciğer yağlanması durumunda oluşacak yatalak sendromunda apolipoprotein B-100 ve A-1'in seviyeleri araştırılmış, toplam 55 hayvandan oluşan çalışma grubu 17 süt humması, 13 süt humması ile beraber ketozis, 12 downer cow syndrome ve 13 downer cow ile birlikte ketozis olarak ayrılmıştır. ApoB-100 ve ApoA-1 konsantrasyonlarının her dört grupta da azaldığı tespit edilmiş olup bu parametrelerin ayağa kalkamayan ineklerde yatalaklığın asıl sebebinin altında karaciğer yağlanmasının olduğu kanaatine varılmıştır.

Fenwick ve ark. [61] hematolojik parametrelerde WBC artışının haricinde herhangi bir değişiklik olmadığını belirtmiştirler. Onmaz ve ark. [49] ise hemoglobin, MCV ve RBC seviyelerinin azaldığını WBC seviyesinin ise arttığını belirtmişlerdir. Ayrıca WBC seviyesindeki artışın sebebi bacaklarda artan kas hasarına ve dekubitis yaraları ile doku nekrozunun sonucu olarak oluşan yangıya karşı organizmanın savunma sisteminin yanıtı olarak açıklanmıştır [49].

\section{TANI}

Tanı için ana kriter ayağa kalkamama olsa da altında yatan asıl sebebin bulunmas1 gerekir. Klinik bulgular ve anamnez bilgilerine göre teşhis konulabilir. Ancak yatalaklık süresi uzadıkça primer ve sekunder hastalıkların ayırımını yapmak zordur $[8,54]$. Anamnez, klinik bulgular ve laboratuvar bulguları ile tanı konulabilir. Doğum sonrası kalsiyum uygulamasına rağmen ayağa kalkmayan hayvanlarda ilk olarak downer cow akla gelir [8].

Klinik olarak tanı süreci yatalaklığa sebep olacak çeşitli sebepler ile birlikte yatalaklığa bağlı olarak oluşabilecek 
hasarlar tespit edildikten sonra devam etmelidir. Manuel ve rektal muayene ile pelvis ve rektumda olabilecek yumuşak doku hasarı ile krepitasyona göre pelvik veya femoral kırıklar tespit edilebilir. Ayrıca rektal palpasyon ile pelvik lenf nodüllerinde veya uterus'ta olabilecek lenfosarkomlar palpe edilebilir [1].

Doğum sonrası hipokalsemi teşhisiyle 24 saat arayla 2 kez kalsiyum uygulanmasına müteakip hipokalsemi belirtilerinin kaybolması, iştah ve genel durumun düzelmesine rağmen hayvanların ayağa kalkamaması downer cow sendromu olarak değerlendirilir [8].

Laboratuvar muayeneleri genellikle çok kullanışlı değildir. CK ölçümleri yatalaklığın primer sebebini tespit etmekten ziyade kas hasarının derecesini değerlendirmek için kullanılabilir. Aynı şekilde idrar myoglobin ölçümleri de faydalı olacaktır [1, 41]. Süt humması diğer metabolik hastalıklarla komplike olduğunda tanı daha zorlaşır. Biyokimyasal muayenelerin yapılma imkanının olmadığ deneysel olarak $\mathrm{Ca}, \mathrm{Mg}$, $\mathrm{P}$ ve kortikosteroid uygulanarak deneysel tanı yoluna gidilebilir [41].

Yapılan bir araștırmada tanı aşağıdaki tabloda belirtilen şekilde sınıflandırılarak incelenmiştir [23].

Tablo 2: Yatalak inek sendromunda tanı planı [23]

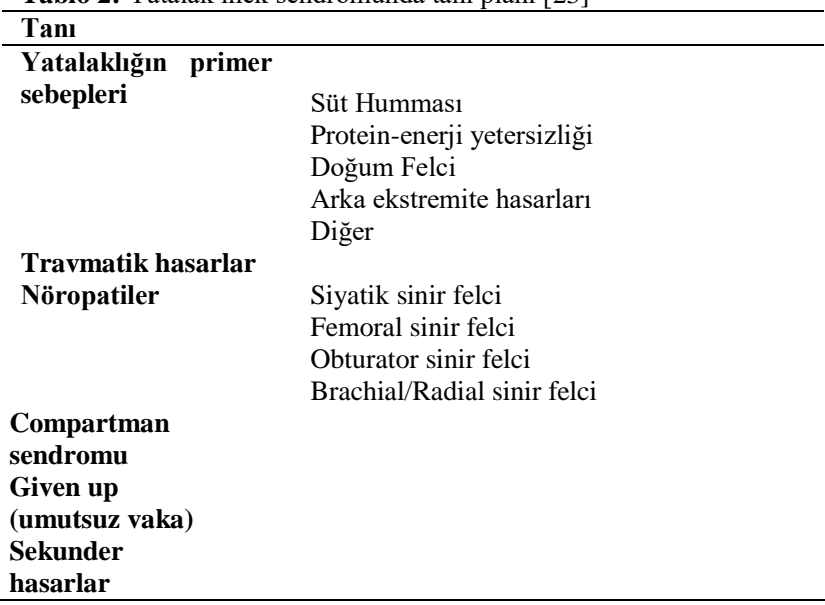

\section{PROGNOZ}

Sürünme eğiliminde bulunan hayvanların prognozu iyidir. Eğer hayvan kaldırılır ve arka bacaklarda kuvvet olmadığ 1 gözlenirse prognoz konusunda tedbirli olunmalıdır. Günlük gözlem ilave bilgiler sunabilir. Yatalak hayvanın kalkması hayvanın kendisine bağlı olduğu kadar yetenekli ve istekli aynı zamanda becerikli bir bakıcıyla iyi bakım koşullarına da bağlıdır [1].

Yatalak ineklerde çok çeşitli primer sebepler bulunması ve sekunder kas ve sinir hasarlarının yüksek oranda olması prognoz konusunda çok değişkenlik sağlar. Anamnez ve dikkatli yapılan fiziksel muayene başarı konusunda çok yardımcı olacaktır [61]. Yatalaklığın primer sebebi olabilecek hipokalsemi ve ketozis gibi metabolik bozukluklar uygun şekilde tedavi edildikten sonra kritik olan prognoz kararı verilmelidir [28]. Bir çalışmada 84 hipokalsemik yatalak inek ilk 6 saat içerisinde tedavi edildikten sonra 83 tanesi ayağa kalkmıştır [62]. Stull ve ark. [28] yatalaklığın sekunder komplikasyonlarının oluşması için kritik süreyi 6 saat olarak belirtmişlerdir. Çiftçiler düzeyinde yapılan bir anket çalışmasına göre, katılımcıların yaklaşık yarısı yatalaklıktan dönen ineklerin ilk 6 saat içerisinde ayağa kalktıklarını ifade etmişlerdir. Bu yüzden 6 saatten uzun süre yatalak kalan ineklerin prognozu zayıf olarak değerlendirilmiştir. Bazı fiziksel muayene bulguları ve kesin tanı konulan durumlar prognozun zayıf olduğuna işaret eder. Kırıklar, kalça eklemi çıkıkları, vertebrada oluşan apse veya neoplaziler, sindirim sistemine ait operatif müdahale ile tedavi edilemeyecek durumlar ve gangrenli mastit durumları her ne kadar iyi bakım şartları oluşturulsa veya uygun tedavi protokolleri uygulansa dahi prognozu olumsuz olarak düşünülmelidir. Aynı şekilde sertleşmiş, şişmiş veya hissiyatı azalmış arka bacakların da prognozu zayıftır [62].

\section{TEDAVI}

Yatalaklığın en etkili yönetimi ve tedavisi üzerine kayda değer ölçüde çok az bilgi bulunmakla beraber kaliteli bakım şartlarının oluşturulmasının iyileşme üzerine olumlu etkileri olduğu belirtilmektedir [20]. Eğer yatalaklık hipokalsemi, hipomagnezemi, mastitis ve metritis gibi spesifik bir hastalıktan kaynaklanıyorsa vakit kaybetmeden asıl hastalığın tedavisi yapılmalıdır [41]. Yatalak hayvanlar genellikle hipokalsemiktir. Eğer hipokalsemik inekler kalsiyum uygulamasına yanıt vermezlerse ve laboratuvar tahlili yapmak mümkün değilse ek olarak $\mathrm{K}, \mathrm{P}$ ve $\mathrm{Mg}$ uygulanabilir. Ancak kan biyokimya göstergeleri downer cow tedavisinin önemli bir parçasıdır [16].

Huxley ve ark. [54] yatalak ineklerin tedavisinde nonsteroid antiinflamatuar ilaçların (NSAI) kullanımını önermişler ve bu amaçla meloksikam, tolfenamik asit, ketoprofen ve fluniksin meglumin kullanılabileceğini belirtmişlerdir. Başka bir araştırmada ise özellikle kas hasarı veya sinir hasarı durumlarında NSAI ilaçların endike olduğu ifade edilerek sekunder nöropati ve myopati durumlarında da kullanılabileceği belirtilmiştir [56].

Myoglobinüri varsa sıv1 tedavisi yapılmalıdır. Hiperkalemi ve asidozise uygun solüsyonlar veya diğer dengeli elektrolit solüsyon uygulamaları yapılabilir. Parturient parezis durumlarında genellikle bir doz kalsiyum tuzlarının uygulanmasina olumlu yanıt alınabilir [26]. Ancak buna rağmen parturient parezisli ineklerin yaklaşı $\% 15$ 'i kalsiyum uygulamasına yanıt vermez [57].

Tedavi yönetiminde, yatalaklık süresince oluşabilecek sekunder zararların önüne geçmek önemli bir husustur [58]. Bu amaçla yapılacak en önemli üç husus, daima ulaşabileceği temiz su ve kaliteli yem, düzenli olarak döndürme ve ayakta durması için kaldırma ile ayağını yere sağlam basabileceği kalın yumuşak bir altlık oluşturulmasıdır [55]. Enerji ve fibrin yönünden yeterli miktarda yemin ve temiz suyun hayvanin her zaman 
kolayca ulaşabileceği yerde, diğer ineklerden uzak olarak bulunması önemlidir [20]. Belloli ve ark. [57] ise önemli bakım koşulları olarak hastaların küçük bir padokta hareketinin kısıtlanması, yatış pozisyonlarının sık sık değiştirilmesi ve her 2 veya 4 saatte bir ayağa kaldırılması olarak belirtmiştir. Merada ve/veya toprakta bulunan hayvanların daha rahat düzelebildikleri görülmüştür. Hayvanların mümkün olduğunca sternal pozisyonda tutulması sağlanmalıdır [10]. Yatalak inekler mastitis riskine karşın 12 saatte bir günde iki kez sağılmalıdır [44].

Fizyoterapi sinir hasarlarının iyileşmesine yardımcı olabilir [56]. Fizyoterapi venöz dolaşımı stimüle ederek ve kas perfüzyonunu arttırarak iskemik myonekrozu sınırlayabilir [44]. Bu amaçla çeşitli uygulamalar yapılabilir. Özellikle arka bacaklara gerdirerek masaj yapmak, manuel olarak ekstensiyon ve fleksiyon hareketleri yaptırılarak hayvan ayağa kalkmaya cesaretlendirilebilir [59]. Dar bir alana sıkıştırıp hareket alanı kısıtlanarak özellikle obturator parezis/paralizis durumunda bacağın normal pozisyonda durması sağlanabilir [44]. Bununla birlikte topuk eklemi hizasından veya tarsal eklem üzerinden köstekle veya iple bağlanarak bacakların adduksiyonu engellenebilir [59].

Atel uygulamaları veya bandajlar bazı nöropatilerde özellikle siyatik ve peroneal felç durumunda topuk eklemine veya parmakları kaplayacak şekilde uygulanarak tedaviye yardımcı olabilir [56, 59]. Kalça kaldıracı veya kalça kepçesi bir metal bar üzerine uçları halkalı ve bar üzerinde hareket edecek şekilde tasarlanmıştır. $\mathrm{Bu}$ alet her iki tuber koksaya geçirilip halkalar kavuşturularak bir kaldıraç yardımıyla ineğin arka kısmının kaldırılmasına olanak sağlar. Yapılan bir anket çalışmasında çiftçilerin $\% 75$ bu yönetimi denediklerini, \%71 ise kullanışlı bulduklarını ifade etmişlerdir [43]. Kalça kaldıracının küçük olması, kullanımının kolay olması ve arka bacakları desteklemesi gibi avantajları varken, hayvan üzerinde sabitlenmek zorunda olması gibi dezavantajı vardır. Alet küçük bir alanda yüksek basınç uygulamaktadır. Eğer fazla sıkılırsa kas dokusuna ve tuber koksanın kemik dokusuna zarar verebilir. Eğer gereğinden az sıkılırsa da hayvan biraz kaldırıldıktan sonra tespit edildiği yerden çıkarak birden düşmesine ve ciddi zarar görmesine sebep olabilir [2]. Şişme hava yastığı, şişme balon veya Cow Jack gibi farklı isimlerle anılan kaldırma yöntemleri aynı prensiple hayvanı ayakta tutmak veya kaldırmak için kullanılır. $\mathrm{Bu}$ yöntem büyük bir silindir şeklinde şişirilebilen materyalin yatan hayvanın altına konulup şişirilmesiyle çalışır. Şişme silindirin çok yumuşak olması ve herhangi bir yumuşak dokuya basınca bağlı olarak zarar vermemesi gibi avantajı varken, yastığın yüksek oranda abdomeni kapsaması ve basınçtan dolayı iç organlara ve diyaframa baskı yaparak solunum üzerine negatif etkisinin olması gibi dezavantajı vardır [1]. Hem kalça kaldıracı hem de şişirilebilir yataklar benzer problemlere sahiptir. Bu yöntemler büyük ve ağır inekler için yeterli desteği sağlayamamaktadır [2]. Lastein [2] tarafından 1970'lerin sonlarında kendi yatalak hayvanlarını tedavi etmek amacıyla geliştirilen, flotasyon tekniği de benzer prensiplerle çalışmaktadır. Özel olarak tasarlanmış bir tanka, yatalak hayvan bir halı içine sarılıp bir kaldıraç yardımıyla alındıktan sonra içerisine su doldurularak kalkmasına yardım edilmeye çalışılmıştır [56]. Bu teknik araştırmacılar tarafından birkaç araştırmada kullanılmış ve \%37-46 oranında başarılı bulunmuştur [7,56,60]. Tekniğin olumsuz yönleri, hayvanın tanka alınmasının zor olması, büyük miktarda sıcak suya ihtiyaç duyulması ve hayvanda hipertermi veya hipotermi riski barındırması olarak belirtilmiştir. Hayvanın rahat bir şekilde ayağa kalkarak uzun süre ayakta tutulabilmesi ve oluşturulan kuvvetin tüm vücuda eşit olarak yayılması ise avantaj olarak belirtilmiştir [2].

\section{KORUNMA}

Korunma için yapılması gerekenler beș başlık altında incelenebilir; 1) Süt humması riskini en aza indirmek; 2) Gebelik süresince doğru besleme programı uygulamak ve doğuma optimum vücut kondisyonunda girmesini sağlamak; 3)Teşhis edilen metabolik hastalıklara hızla ve doğru müdahalede bulunmak, 4)Uygun boğa kullanarak, büyük buzağı doğumlarını ve güç doğumları engellemek, 5) Doğum bölmelerine yumuşak ve uygun altlık sağlamak [41].

Yapılan bir çalışmada laktasyona yatalak olarak giren ineklerin sorunsuz olarak giren ineklere göre sürüden çıkarılma oranının 3,5 kat fazla olduğu gösterilmiştir [64]. Veteriner hekimlerin öncelikli hedeflerinden biri üreticilere sürü yönetimi ve yatalaklığın önlenmesi konusunda yardımcı olmaktır. Veteriner hekimler geniş alanlarda uygun besleme programları, sürü sağlığı ve yönetimi, hayvan refahı, temizlik ve sanitasyon, doğum prosedürleri ve tesisler konularında önerilerde bulunmalıdırlar [26,28]. Yatalaklığın önemli risk faktörleri, hipokalsemi ve doğum ile ilişkili komplikasyonlar ve yaralanmalardır. $\mathrm{Bu}$ nedenle periparturient inekler yakından izlenmelidir. $\mathrm{Bu}$ amaçla video kayıtlı kamera sistemleri uygun bir seçenektir [51]. İneklerde topallığı en aza indirmek yatalaklığın oluşumunu engellemeye katkıda bulunacaktır. Özellikle periparturient dönemdeki ineklerin sessiz, sakin ve kaygan olmayan zeminde bulunması doğum ve düşmeye bağlı yaralanmaların önüne geçmeye yardımcı olacaktır [64].

\section{KAYNAKLAR}

[1] Cox VS. Nonsystemic causes of the downer cow syndrome. Vet Clin Food Anim Pract. 1988; 4: 413-433.

[2] Dahlberg J. Flotation therapy for downer cows. Examensarbete. 2012; 28:5-27

[3] Björsell A, Holtenius K, Jacobsson P. Studies on parturient paresis with special reference to the downer cow syrdrome. Acta Vet Scand. 1969; 10: 36-43.

[4] Fenwick DJ. Parturient paresis (milk fever) of cows. 1. The response to treatment and the effect of the duration of symptoms. Aust Vet J. 1969; 45: 111-113. 
[5] Cox VS. Understanding the downer cow syndrome. Comp Cont Ed. 1981; 3: S472-S478.

[6] Angelos JA, Smith BP. Down cows (Alert downers). In: Smith BP, editor. Large Animal Internal Medicine. 5th ed. California: Mosby; 2002. p. 1013-1014.

[7] Burton AJ, Nydam DV, Ollivett TL, Divers TJ. Prognostic indicators for nonambulatory cattle treated by use of a flotation tank system in a referral hospital: 51 cases (1997-2008). J Am Vet Med Assoc. 2009; 234: 1177-1182.

[8] Gül Y, İssi M, Deveci H. Süt ineklerinde yatalak hal (Recumbent cow, Festligende küh). Frrat Univ Sag Bil Derg. 2007; 21:179-182.

[9] Curtis RA, Cote JF, Willoughby RA. The downer cow syndrome a complication, not a disease. J Am Vet Med Assoc. 1970; 51: 25-28.

[10] Güneş V. Yatalak inek sendromu. Türkiye Klinikleri J Vet Sci. 2011; 2: 151-157.

[11] Green A, Lombard J, Garber L, Wagner B, Hill GJ. Factors associated with occurrence and recovery of nonambulatory dairy cows in the United States. J Dairy Sci. 2008; 91: 2275-2283.

[12] Radostits OM GC, Hinchvliff KW, Constable PD. Veterinary Medicine. 10th ed. Philadelphia: Saunders Elsevier; 2006.

[13] Jönsson G, Pehrson BJ. Studies on the downer syndrome in dairy cows. Zbl Vet Med. 1969; 16: 757-784.

[14] Chénier S, Leclère M, Messier S, Fecteau G. Streptococcus dysgalactiae cellulitis and toxic shock-like syndrome in a Brown Swiss cow. J Vet Diagn Invest. 2008; 20: 99-103.

[15] Blood DC, Henderson JA, Radostits OM. Veterinary Medicine. 5th ed. London: Bailliere Tindall; 1979.

[16] Berchtold J. Musculoskeletal System. In: Khan CM, Line S, editors. The Merck Veterinary Manual. 10th ed. New Jersey: Merck and Co; 2010. p. 1082-1086.

[17] Smith B, George L, Angelos S, House J. Down cows: causes and treatments. Proc Am Assoc Bovine Pract Conv. 1997; 43-45.

[18] Van Metre D, Callan R, Garry FJ. Downer cowsDiagnosis and assessment. Proc Annu Meet Coll Vet Intern Med. 2003; 318-320.

[19] Raja S, Vajayarajan A, Palanisamy M, Prabaharan $\mathrm{V}$, Rajkumar R, Jayaganthan P. An overview of peripartum downer cow and its fertility. Indian Farmer. 2018; 5: 608-614.

[20] Poulton P. Examination, diagnosis, prognosis and management of downer cows. PhD, Melbourne: Melbourne University; 2015.

[21] Julien WE, Conrad H, Redman DJ. Influence of dietary protein on susceptibility to alert downer syndrome. J Dairy Sci. 1977; 60: 210-215.

[22] Cox VS, McGrath C, Jorgensen SJ. The role of pressure damage in pathogenesis of the downer cow syndrome. Am J Vet Res. 1982; 43: 26-31.

[23] Poulton P, Vizard A, Anderson G, Pyman MJ. Importance of secondary damage in downer cows. Aust Vet J. 2016; 94: 138-144.
[24] Pehrson B. Studien Über Das Festliegen (DownerSyndrome) Bei Milchkühen, Atypisches Festliegen Beim Rind. Kongressband Internationaler Workshop; 2002.

[25] Goff JP. Macromineral disorders of the transition cow. Vet Clin Food Anim Pract. 2004; 20: 471494.

[26] Correa MT, Erb HN, Scarlett JMJ. Risk factors for downer cow syndrome. J Dairy Sci. 1993; 76: 3460-3463.

[27] Cox VS, Farmsworth RJ. Prevention and treatment of down cows: a continuum, in Proceedings. 31st Annu Conf Am Assoc Bovine Pract. 1998;167-169.

[28] Stull CL, Payne MA, Berry SL, Reynolds JPJ. A review of the causes, prevention, and welfare of nonambulatory cattle. J Am Vet Med Assoc. 2007; 231: 227-234.

[29] Bostancı MA. Yüksek süt verimine sahip ineklerde doğum felcinin profilaksisinde diyeter magnezyum sülfat'ın önemi. Doktora Tezi, Konya: Selçuk Üniversitesi; 2002.

[30] Klimienė I, Špakauskas V, Matusevičius AJ. Correlation of different biochemical parameters in blood sera of healthy and sick cows. Vet Res Commun. 2005; 29: 95-102.

[31] Oikawa S, Katoh NJC. Decreases in serum apolipoprotein B-100 and AI concentrations in cows with milk fever and downer cows. Can J Vet Res. 2002; 66: 31-34.

[32] Sevinç, M. Sütçü ineklerde doğum felcınin karaciğer yağlanması ile ilgisi, Doktora Tezi, Konya:Selçuk Üniversitesi; 1994.

[33] Martens H, Schweigel MJ. Pathophysiology of grass tetany and other hypomagnesemias: implications for clinical management. Vet Clin Food Anim Pract. 2000; 16: 339-368.

[34] Peek SF, Divers T, Guard C, Rath A, Rebhun WJ. Hypokalemia, muscle weakness, and recumbency in dairy cattle. Vet Ther. 2000; 1: 235-244.

[35] Oem JK, Chung JY, Roh IS, Kim HR, Bae YC, Lee $\mathrm{KH}$, et al. Characterization and phylogenetic analysis of Bovine viral diarrhea virus in brain tissues from nonambulatory (downer) cattle in Korea. J Vet Diagn Invest. 2010; 22: 518-523.

[36] Rulff R, Schrödl W, Basiouni S, Neuhaus J, Krüger MJ. Is downer cow syndrome related to chronic botulism?. Pol J Vet Sci. 2015; 18: 759-765.

[37] Rukkwamsuk T, Kruip T, Wensing TJ. Relationship between overfeeding and overconditioning in the dry period and the problems of high producing dairy cows during the postparturient period. Vet Q. 1999; 21: 71-77.

[38] Collins R, Reid IJ. A correlated biochemical and stereological study of periparturient fatty liver in the dairy cow. Res Vet Sci. 1980; 28: 373-376.

[39] Rehage J, Qualmann K, Meier C, StockhofeZurwieden N, Hoeltershinken M, Pohlenz JJ. Total serum bile acid concentrations in dairy cows with fatty liver and liver failure. Dtsch Tierarztl Wschr. 1999; 106: 26-29.

[40] Staufenbiel R, Staufenbiel B, Rossow N, Klukas H, Johannsen U. Diagnostik der leberverfettung bei 
der milchkuh. Dtsch Tierärztl Wschr. 1993; 100: 209-248.

[41] Allen W, Davies DJB. Milk fever, hypomagnesaemia and the 'downer cow syndrome'. Vet J. 1981;137: 435-441.

[42] Erb H, Grohn YJ. Epidemiology of metabolic disorders in the periparturient dairy cow. J Dairy Sci. 1988; 71: 2557-2571.

[43] Cox VS, Marsh WE, Steuernagel GR, Fletcher TF, Onapito JSJ. Downer cow occurrence in Minnesota dairy herds. Prev Vet Med. 1986; 4: 249-260.

[44] Huxley JJ. Assessment and management of the recumbent cow. In Practice. 2006; 28: 176-184.

[45] Stöber M, Dirksen G. The recumbent cow: differential diagnosis and differential therapy. Vet Ann. 1982; 22: 81-94.

[46] Yilmaz Z. Downer cow sendromu. Veteriner Cerrahi Dergisi. 2000; 6: 85-88

[47] Andrews T. The 'downer cow'. In Practice. 1986; 8: $187-189$

[48] Güzelbekteş H, Coşkun A, Öztürk AS, Şen İ, Ok M. Yatalak ineklerde kan gazları, hematolojik ve bazı biyokimyasal değişiklikler. Vet Bil Derg. 2006; 22:5-10.

[49] Onmaz AC, Aytekin I, Aypak SU, Gunes V, Kucuk O, Ozturk AS. Trace elements and biochemical and haematological parameters in cows with downer syndrome. Bull Vet Inst Pulawy. 2011; 55: 525528.

[50] Rulff R, Schrödl W, Basiouni S, Krüger MJ. Biochemical investigations and glyphosate detection in downer cow syndrome. Intl J Sci Eng Res. 2016; 7: 1548-1553.

[51] Cox VS. Pathogenesis of the downer cow syndrome. Vet Rec. 1982; 111: 76-79.

[52] Clark R, Henderson H, Hoggard G, Ellison R, Young BJ. The ability of biochemical and haematological tests to predict recovery in periparturient recumbent cows. N Z Vet J. 1987; 35: 126-133.

[53] Kachhawaha S, Tanwar RJ. Biochemical and enzymatic changes in downer cow syndrome. Indian J Anim Sci. 2010; 80: 338-339.

[54] Huxley J, Archer S, Biggs A, Bradley A, Breen J, Green $\mathrm{M}$, et al. An expert review of the diagnosis, prognosis and treatment of recumbency in adult cattle. Cattle Practice. 2010; 18: 53-60.

[55] Smith-Maxie, L. Diseases of the nervous system. In: Greenough PR, Weaver AD, editors. Lameness in cattle. Philadelphia: Saunders; 1997. p. 203-218.

[56] Caple IW. Downer cow syndrome. In: Howard JL, editor. Current Veterinary Therapy Food Animal Practice. 2nd ed. Philadelphia, London, Toronto: WB Saunders Company; 1986. p. 327-328.

[57] Belloli A, Arrigoni S, Guarneri DJ. Approccio clinico della "Sindrome della vacca a terra". Large Animal Review. 1996; 2: 19-24.

[58] Parkinson TJ, Vermunt JJ, Malmo J. Diseases of cattle in Australasia: A Comprehensive Textbook. 1th ed. New Zealand: New Zealand Veterinary Association Foundation for Continuing Education; 2010. p. 541-547.
[59] Giudice E, Gianesella MJ. Hydro-physiotherapy in the "downer cow" rehabilitation. Large Animal Review. 2010; 16: 125-131.

[60] Van Metre DC, Callan RJ, Garry FB. Examination of the musculoskeletal system in recumbent cattle. Comp Cont Educ. 2001; 23: S5-S24.

[61] Fenwick D, Kelly W, Daniel RC. Definition of a non-alert downer cow syndrome and some case histories. Vet Rec. 1986; 118: 124-128.

[62] Tulleners E, Nunamaker D, Richardson DJ. Coxofemoral luxations in cattle: 22 cases (19801985). J Am Vet Med Assoc. 1987; 191: 569-574.

[63] Milian-Suazo F, Erb HN, Smith RD. Descriptive epidemiology of culling in dairy cows from 34 herds in New York state. Prev Vet Med. 1988; 6: 243-251.

[64] Grandin T. Welfare of cattle during slaughter and the prevention of nonambulatory (downer) cattle. J Am Vet Med Assoc. 2001; 219:1377-1382. 